IBAD Sosyal Bilimler Dergisi

IBAD Journal of Social Sciences

dergipark.org.tr/ibad

IBAD, 2021; (11): 93-110

DOI: 10.21733/ibad.892197

Özgün Araştırma / Original Article

\title{
Teachers Views About Energy Education and Energy Literacy
}

\section{Enerji Eğitimi ve Enerji Okuryazarlı̆̆ı Hakkında Öğretmen Görüşleri}

\section{Vildan Boz ${ }^{1^{*}}$}

Aslı Görgülü-Arı²

\section{* Sorumlu yazar \\ Corresponding author}

${ }^{1}$ Doktora Öğrencisi, Yıldız Teknik Üniversitesi, Türkiye

PhD. Student, Yıldız Technical University, Turkey

bozvilldan@gmail.com

ORCID ID 0000-0003-3997-8543

${ }^{2}$ Doç. Dr., Yıldız Teknik Üniversitesi, Türkiye, Assoc. Prof. Dr., Yıldız Technical University, Turkey, agorgulu@yildiz.edu.tr

ORCID ID 0000-0002-6034-3684

Makale geliş tarihi / First received : 06.03.2021

Makale kabul tarihi / Accepted : 12.05 .2021

\section{Bilgilendirme / Acknowledgement:}

Yazarlar aşağı daki bil gilendirmeleri yapmaktadırlar:

1- Araştırmacılar tez yazım sürecinde ve tezin makaleye dönüştürülme sürecinde ortak bir çalışma yürütmüştür. Makalenin dergiye sunumu, takip edilmesi ve sonlandırılması sürecini birinci yazar yapmıştır.

2- Makale ikinci yazarın danışmanlığında birinci yazarın yüksek lisans tezinden üretilmiştir

3- Makalenin yazarları arasında çıkar çatışması bulunmamaktadır.

4- Araştırmanın verileri 2019 yılında toplanmıştır.

5- Bu makalede araştırma ve yayın etiğine uyulmuştur.

This article was checked by iThenticate. Similarity Index $16 \%$

\section{Atıf bilgisi / Citation:}

Boz, V., Görgülü Arı, A. (2021). Teachers views about energy education and energy literacy. IBAD Sosyal Bilimler Dergisi, (11), 93-110. 
ÖZ

Araştırmada lise fizik, kimya ve biyoloji öğretmenlerinin enerji okuryazarlığı ve enerji eğitimi hakkındaki görüşlerini belirlemek amaçlanmıştır. Araştırma aynı zamanda ön çalışmaya dayanmaktadır ve ön çalışmada elde edilen sonuçlar öğrencilerin enerji kaynakları konusunda yeterli bilgiye sahip olmadığını ve enerji kaynakları ile ilgili kavram yanılgıları bulunduğunu göstermiştir. Bu durumdan yola çıkılarak, katılımcılara araştırmanın da amacı doğrultusunda sorular sorulmuştur. Araştırma, nitel araştırma modellerinden durum çalışması deseniyle yürütülmüştür. Araştırma grubunu, fizik, kimya ve biyoloji öğretmeni olarak çalışan, araştırmaya gönüllü olarak katılan yedi öğretmen oluşturmaktadır. Öğretmenlerin görüşlerini belirlemek için veri toplama aracı olarak sekiz açık uçlu sorudan oluşan yarı yapılandırılmış görüşme formu kullanılmıştır. Verilerin analizi için görüşme sırasında öğretmenlerin verdikleri cevaplardan yola çıılarak kodlar oluşturulmuş ve frekans tabloları hazırlanmıştır. Araştırmanın güvenirliliğinin sağlamak amacıyla, veriler bir alan eğitimi uzmanı tarafından incelenerek kodlayıcılar arası güvenirlik değeri hesaplanmıştır. Araştırma sonucunda öğretmenler, ilgili öğretim programlarının yetersiz olmasından dolayı, öğrencilerin enerji konusundaki bilgi eksikliklerinin olduğunu düşünmektedirler. Araştırma sonucunda elde edilen bulgular dikkate alınarak, enerji okuryazarlığı eğitiminin küçük yaşlarda başlaması, enerji konularının öğretiminde görsel materyallerin kullanılması gibi önerilerde bulunulmuştur.

\section{Anahtar kelimeler}

Enerji eğitimi, enerji okuryazarlığı, fen eğitimi, fizik öğretmeni, kimya öğretmeni, biyoloji öğretmeni.

\section{ABSTRACT}

This study aimed to determine the opinions of high school physics, chemistry and biology teachers about energy literacy and energy education. The research is also based on the preliminary study, and the results obtained in the preliminary study showed that the students did not have sufficient knowledge about energy resources and that they had misconceptions about energy resources. Based on this situation, the participants were asked questions in line with the purpose of the study. The research was carried out with a case study design, which is one of the qualitative research models. The research group consists of seven teachers who work as physics, chemistry, and biology teachers who voluntarily participate in the research. A semi-structured interview form consisting of eight open-ended questions used as a data collection tool to determine teachers' views. For the analysis of the data, codes created based on the answers given by the teachers during the interview and the frequency tables were prepared. To ensure the reliability of the study, the data were examined by a field education expert and the reliability value between coders was calculated. As a result of the research, it was determined that teachers think that students have sufficient knowledge about energy due to the inadequacy of the curricula. Considering the findings obtained as a result of the research, suggestions have made as starting energy literacy education at an early age and using visual materials in teaching energy subjects.

\section{Keywords}

Energy education, energy literacy, science education, physics teacher, chemistry teacher, biology teacher 


\section{INTRODUCTION}

The world is changing very rapidly. People, cities, and everyday life are highly different than they were a hundred years ago. A new way of life brings many different definitions of things. With the changing world and developing technology educational needs have also become different. Like many other things, now, we have recently emerged literacies, and energy literacies is one of them. Aşıcı (2009), Çakmak (2013) and Altun (2015) define literacy as a broad term that includes many cognitive skills such as reasoning, problem-solving, and creative thinking, covering the process of acquiring knowledge and gaining skills required by the age.

Energy is the most important thing for living things and our changing world. Also, energy is going to be the most important issue for the future. In the age we live, with the development and widespread of technology worldwide, individuals' energy usage increases in every field starting from our daily life. This situation causes the amount of energy consumed to reach serious levels. The increase in energy consumption affects many areas, especially the economy (Oral \& Özdemir, 2017). Fossil fuels such as coal, natural gas, and oil are preferred intensively to supply energy needs (Göcük, 2015; Kanlı \& Kaplan, 2018). With the increase in the use of fossil fuels, the environmental damage they have started to increase. Also, fossil fuel sources are running out rapidly. This led to a trend towards sustainable and renewable energy sources, and also increased the importance of energy education and energy literacy.

Energy literacy is to understand the role of energy in the universe and our lives, to find answers to energy-related questions, and to solve energy-related problems (Merritt, Bowers, \& RimmKaufman, 2019). With this understanding, individuals are able to make emotionally and behaviorally conscious choices (DeWaters \& Powers, 2011; Öykün \& Abbasoğlu, 2017). The energy literate individual in several sources is defined as the one who:

- has a basic conceptual knowledge of energy resources;

- knows how energy is obtained, for what purpose it is obtained and how much energy is used;

- understands the issues pertaining to the obtainment of renewable and non-renewable resources;

- knows the use of energy in daily life;

- evaluates the accuracy of information about energy;

- is sensitive to energy-saving and developing alternative sources of fossil fuels;

- a follower of the decisions taken regarding the use and selection of energy resources;

- can make informed energy use decisions by considering the effects and results of resource usage;

- contributes to decision making with regard to energy development and consumption (Kuhn, 1980; Valhov \& Treagust, 1988; Dewaters \& Powers, 2011; Bodzin, et. al., 2013; Göcük, 2015).

Besides, energy literacy means to notice the social and global effects of energy resources (Fah, Hoon, Munting \& Chong, 2012). In addition to it is the responsibility of all people to support solutions related to energy-based problems. Therefore, it is important that individuals are getting enough education in terms of energy literacy.

Nowadays, since technology is widely used in our lives, the increasing energy need requires conscious consumption. Hence, energy education is significant for individuals' awareness of 
energy-related issues. If people gain awareness about energy, sustainability, and the conscious usage of energy resources increase.

A literature review was conducted for studies on energy literacy. Martins, Madaleno and Dias (2019), in their study, they intended to analyze how the education field influences the levels of energy literacy. They found that the levels of energy literacy are moderate, and also they did not find significant differences between the distinct educational fields that were analyzed.

Merritt et al. (2019) investigate the energy literacy development in fourth-grade classrooms. They obtained the data with open-ended questions and then, they used qualitative methods to analyze students' open-ended responses from an energy literacy assessment. They found that students learned the important energy and natural resource concepts and power plants are useful contexts for helping students to connect electricity use and climate change.

Öykün and Abbasoğlu (2017) aim to evaluate energy awareness and existing knowledge about energy issues, behavior, and attitudes of students. They found that the overall knowledge level of the students on energy issues is very low.

In the study, Göcük (2015) aims to find out how problem-based learning influences the fifthgrade students' energy literacy improvement by using attitude and knowledge tests. It is found that problem-based learning is efficient in developing student's energy literacy in terms of their attitudes, behaviors, and knowledge.

DeWaters and Powers (2011) investigate the energy literacy on secondary students in New York. They found that the students are concerned about energy problems, besides they may lack of knowledge and skills that they need to effectively contribute toward solutions about energy issues. Also, they emphasize the need for education that improves energy literacy by impacting student attitudes, values, and behaviors.

When the research in the literature are analyzed, it is seen that there are not enough studies that include the opinions of teachers on energy literacy. Also, in recent years there has been a growing concern regarding environmental issues and energy consumption problems. Increasing energy usage causes environmental problems such as air pollution, harms to water sources, water scarcity. Therefore, conscious energy conception gained importance. Efficient energy consumption is significant for today and the future. In this sense, energy education is important, and individuals should be made aware of this issue and ensured to make the right choices.

Teachers' teachings play a role in the choices of individuals throughout life. Therefore, teachers' knowledge and views are important for raise individuals' consciousness and provide awareness about this issue. The teacher who aware of the problems about energy will raise student's raise of the same consciousness. In addition to these, by examining the high school physics (MEB, 2018b), chemistry (MEB, 2018c), and biology (MEB, 2018a) curricula, Table 1 includes the acquisitions related to energy and energy resources. 
Table 1. The Physics, Chemistry, and Biology Course Acquisitions

\begin{tabular}{|c|c|c|c|}
\hline $\begin{array}{l}\text { Course } \\
\text { Name }\end{array}$ & $\begin{array}{l}\text { Class } \\
\text { Level } \\
\end{array}$ & Acquisitions & $f$ \\
\hline \multirow{4}{*}{ Physics } & \multirow{4}{*}{$9^{\text {th }}$ Grade } & 9.4.4.1. Explain the concept of yield. & \multirow{4}{*}{4} \\
\hline & & $\begin{array}{l}\text { 9.4.5.1. Evaluates renewable and non-renewable energy } \\
\text { sources in terms of advantages and disadvantages. }\end{array}$ & \\
\hline & & $\begin{array}{l}\text { 9.5.4.3. It designs for the insulation of living spaces for } \\
\text { energy saving. }\end{array}$ & \\
\hline & & $\begin{array}{l}\text { 9.5.4.5. It develops projects for precautions to be taken } \\
\text { against global warming. }\end{array}$ & \\
\hline Biology & $10^{\text {th }}$ Grade & $\begin{array}{l}\text { 10.3.3.1. Explain the importance of sustainability of natural } \\
\text { resources. }\end{array}$ & 1 \\
\hline \multirow{4}{*}{ Chemistry } & $9^{\text {th }}$ Grade & $\begin{array}{l}\text { 9.5.1.2. It develops solutions for water saving and } \\
\text { protection of water resources. }\end{array}$ & 1 \\
\hline & & $\begin{array}{l}\text { 12.4.1.1. Offers solutions to reduce the harmful effects of } \\
\text { fossil fuels on the environment. }\end{array}$ & \multirow{3}{*}{3} \\
\hline & $12^{\text {th }}$ Grade & 12.4.2.1. Recognizes alternative energy sources. & \\
\hline & & $\begin{array}{l}\text { 12.4.2.2. Evaluates the use of nuclear energy in terms of } \\
\text { science, society, technology, environment and economy. }\end{array}$ & \\
\hline
\end{tabular}

When Table 1 is determined, it is seen that the acquisitions related to energy resources and energy literacy were in the physics course curriculum (MEB, 2018b) only for 9th-grade level. It is seen that acquisitions are included in only at the 10th grade in the biology course curriculum (MEB, 2018a), and in the chemistry curriculum (MEB, 2018c), at the 9th and 12th grade are included. Also, it is seen that most acquisitions are in the comprehension level of the cognitive domain (Ayyıldız, Aydın \& Nakiboğlu, 2019). When we consider Table 1 in general, the acquisitions on the subject of energy resources in high school physics, chemistry, and biology curricula are limited.

Consider all this, this study is significant for understanding and determining teachers' perspectives on energy education. This study also depends on a preliminary study on secondary school students' views about energy sources. The results obtained in the previous study and based on the lack of literature on the purpose of the research; to get the opinions of secondary school physics, chemistry and biology teachers about the lack of knowledge of students on energy issues, energy education and energy literacy. In addition to this purpose and the main research question "What do teachers think about energy literacy?" the questions to be answered are present below.

- What do teachers think about the characteristics of energy literate individuals?

- What do teachers think about the importance of energy literacy for Turkey?

- What do teachers think about the changes that students' awareness of energy will create in society?

- What do teachers think to be include in the scope of the issues related to energy resources?

- What do teachers think about the teaching materials for using in raising energy literate individuals? 
- What do teachers think about out-of-school learning environments be using in the teaching of energy-related subjects?

- What do teachers think about the lack of knowledge of students on energy issues?

\section{RESEARCH METHODOLOGY}

\section{Research Design and Sample}

In this study, case study method is used which is one of the qualitative research methods. The sample group of the research consists of seven teachers who working at physics, chemistry and biology in different public and private secondary schools in Istanbul. Ten people reached in the context of research, but only seven of these people volunteered to participate in the study. The research group was determined by the purposeful sampling method. In purposeful sampling method, information-rich cases are selected for in-depth study, and persons, events, objects, or situations that meet certain criteria are included in the sample (Welsh \& Rivers, 2011; Büyüköztürk et. al, 2016). In this regard, teachers who have experienced 10 years or more and have given lessons on energy resources in the previous professional years were chosen as samples. A total of seven physics, chemistry and biology teachers each was coded in the tables as Physics Teacher 1 (PT1), Physics Teacher 2 (PT2), Biology Teacher 1 (BT1), Biology Teacher 2 (BT2), Biology Teacher 3 (BT3), Chemistry Teacher 1 (CT1), and Chemistry Teacher 2 (CT2) according to their branches by the researchers.

In Table 2, demographic characteristics such as gender, age, years of experience, branch, type of school and graduation status of teachers are given.

Table 2. The Demographic Characteristics of Teachers

\begin{tabular}{ccc}
\hline $\begin{array}{c}\text { Teacher } \\
\text { Code }\end{array}$ & $\begin{array}{c}\text { Years of } \\
\text { Experience }\end{array}$ & Profession \\
\hline PT1 & 16 & Physics Teacher \\
\hline PT2 & 13 & Physics Teacher \\
\hline BT1 & 29 & Biology Teacher \\
\hline BT2 & 21 & Biology Teacher \\
\hline BT3 & 12 & Biology Teacher \\
\hline CT1 & 19 & Chemistry Teacher \\
\hline CT2 & 20 & Chemistry Teacher \\
\hline
\end{tabular}

In Table 2, the demographic characteristics of the teachers are given. According to the table, two of the teachers provide education in physics, three in biology, and two in chemistry.

\section{Research Instrument and Procedure}

In the research, a semi-structured interview technique was used as a data collection tool to obtain the opinions of secondary school physics, chemistry and biology teachers on energy literacy and deficiencies related to energy resources in students. The semi-structured interview is a preferred interview type in qualitative research because it enables to collect in-depth information from the participant and to reorganize questions during application (Wengraf, 2001; Savin-Baden \& Howell Major, 2013; Karasar, 2014).

In the research, a semi-structured interview form, which consists of eight open-ended questions, was used as a measurement tool. First, the measurement tool was improved as a thirteen 
questions interview form by the researcher. Then, the interview form has reduced to eight questions in line with the opinions of three field education specialists. The final version of the semi-structured interview questions was re-examined by the field education specialist. Besides, in the process of preparing the questions, articles, master's, and doctoral theses on energy and energy resources were examined to ask questions that were not asked before. Parallel to the purpose of the study, teachers were asked questions about energy literacy, the contributions of energy literacy to Turkey, and the reflection of informing students about energy resources on society.

The research data were collected from volunteer participants in which the participants can express themselves easily and by recording the voice in the appropriate periods for the participants. Interview questions were directed to each teacher with the same words, and the interviews took for an average of 10-20 minutes with each teacher. The data collection process took approximately one month.

\section{Data Analysis and Interpretation}

For the analysis of semi-structured interviews, the records that taken during the interview were transcript and analyzed. First of all, the data were divided into categories by writing them down. Later on, based on the answers of the teachers, codes were constituted and frequency tables were prepared. At this stage, assistance was received from the study of Ültay, Akyurt and Ültay (2021).

\section{Validity and Reliability}

Merriam (as cited in, Calp, 2020) in his study proposed various strategies such as getting opinions from a field specialist about the findings in order to ensure internal validity in the case studies. So, to ensure the reliability of the research, the data were also examined by a field specialist. Besides, the reliability calculation of the analysis of the data had made by using Miles and Huberman's (1994)'s reliability formula. Accordingly, reliability was calculated based on the Reliability $=$ Consensus $/$ (Consensus + Disagreement) x 100 reliability formula (Miles \& Huberman, 1994). The value that was obtained as a result of the calculation is $89 \%$ (R: $62 /(62+8)$ $x 100=89$ ). According to the coding control that gives the reliability, the co-agreement between the coders is expected to be at least 70\% (Miles \& Huberman, 1994; Patton, 2002). Consequently, it was determined that the value of the Miles-Huberman reliability formula for teachers was above $80 \%$ and this shows that the researcher's coding is reliable.

\section{RESULTS}

In this section, the findings obtained from the answers given by the high school physics, chemistry and biology teachers to the semi-structured interview questions for the purpose of the study are included.

Table 3 presents the teachers' answers to the question "What do you think is energy literacy? How would you describe it?". 
Table 3. Teachers views on energy literacy

\begin{tabular}{llc}
\hline \multicolumn{1}{c}{ Code } & $f$ & Teacher Code \\
\hline To have knowledge about energy & 5 & $\begin{array}{c}\text { PT1, BT1, BT2, BT3, } \\
\text { CT1 }\end{array}$ \\
\hline To know the benefits and harms of energy & 3 & BT2, CT1, CT2 \\
\hline Knowing the types of energy & 3 & BT2, BT3, CT1 \\
\hline Using energy economically/efficiently & 2 & PT1, BT2 \\
\hline Energy production methods, etc. to have knowledge on issues & 2 & PT1, BT2 \\
\hline Energy issue becomes understandable & 1 & PT2 \\
\hline To relate the energy issue with daily life & 1 & PT2 \\
\hline Having awareness about energy & 1 & CT2 \\
\hline
\end{tabular}

When Table 3 is analyzed, it is seen that five teachers define energy literacy as knowing energy. Three teachers defined energy literacy as knowing the benefits and harms of energy, while three teachers interpreted knowing the types of energy. Besides, two teachers have defined energy literacy as using energy economically, and two teachers know such as energy production methods. Also, they stated that energy literacy is to have knowledge about the correct use and obtaining of energy and to use energy economically. While a teacher defines energy literacy as making the energy issue understandable, a teacher has defined the issue of energy as being able to relate to daily life and another teacher to be aware of energy.

Table 4 presents the teachers' answers to the question "What do you think are the features that an energy literate individual should have?".

Table 4. Characteristics of energy literate individuals

\begin{tabular}{lcc}
\hline \multicolumn{1}{c}{ Code } & $f$ & Teacher Code \\
\hline Being knowledgeable and conscious about energy & 5 & $\begin{array}{c}\text { BT1, BT2, BT3, } \\
\text { CT1, CT2 }\end{array}$ \\
\hline $\begin{array}{l}\text { Should be informed about waste of energy } \\
\text { He cares about his country }\end{array}$ & 4 & $\begin{array}{c}\text { BT2, BT3, CT2, } \\
\text { CT1 }\end{array}$ \\
\hline Have knowledge about the production stages of energy & 2 & PT1, BT1, CT2 \\
\hline BT2, CT1 \\
\hline Harticipating in studies on the protection of resources & 2 & CT1, CT2 \\
\hline Paying attention to the environment and ecosystem & 1 & PT2 \\
\hline
\end{tabular}

When Table 4 is analyzed, five of the participants stated that an energy literate individual should be knowledgeable and conscious about energy, while four stated that they should be informed about waste of energy. Three of the participants think that the individual who is an energy literate person cares about his country, two of them have knowledge about the production stages of energy, and two of them are participate in studies on the protection of resources. Also, one of the participants stated that an energy literate individual should have an interest in the energy issue, and one participant should pay attention to the environment and ecosystem. 
Table 5 presents the teachers' answers to the question "What is the importance of energy literacy for our country?".

Table 5. The importance of energy literacy for our country

\begin{tabular}{lcc}
\hline \multicolumn{1}{c}{ Code } & $f$ & $\begin{array}{c}\text { Teacher } \\
\text { Code }\end{array}$ \\
\hline Important for country development & 3 & $\begin{array}{c}\text { BT1, CT1, } \\
\text { CT2 }\end{array}$ \\
\hline $\begin{array}{l}\text { As the level of knowledge about energy resources } \\
\text { increases, awareness about energy-saving increases }\end{array}$ & 3 & $\begin{array}{c}\text { PT1, BT2, } \\
\text { BT3 }\end{array}$ \\
\hline Public awareness & 2 & PT2, CT1 \\
\hline Increased level of consciousness & 1 & PT2 \\
\hline Important for sustainability & 1 & CT1 \\
\hline
\end{tabular}

According to Table 5, three of the participants stated that energy literacy is important for our country development and three of them are important in terms of increasing awareness about energy-saving. Two of the participants thinks that energy literacy is important for in terms of public awareness. One of the participant stated that energy literacy is important for increased level of consciousness, one is that energy literacy is important in terms of sustainability.

Table 6 presents the teachers' answers to the question "Studies show that students do not have enough information about energy sources, what could be the reason for this situation?".

Table 6. Teachers' views on the knowledge levels of students towards energy resources

\begin{tabular}{lcc}
\hline \multicolumn{1}{c}{ Code } & $f$ & Teacher Code \\
\hline $\begin{array}{l}\text { The curriculum is not sufficient and rich } \\
\text { The subjects remains only at the level of knowledge }\end{array}$ & $\begin{array}{c}\text { PT1, BT1, BT2, } \\
\text { CT1, CT2 }\end{array}$ \\
\hline The use or functioning of energy resources is complex & 3 & PT1, BT2, CT2 \\
\hline Lecture is not interesting & 1 & PT2, BT3 \\
\hline Focusing on university exam topics & 1 & PT1 \\
\hline $\begin{array}{l}\text { Written, visual, etc. the media does not raise awareness on the } \\
\text { issue }\end{array}$ & 1 & CT1 \\
\hline
\end{tabular}

About the lack of adequate knowledge of the student's five of the participants think that the curriculum is not sufficient and rich for students to have enough information about energy resources. Three of the participants think that the subjects remain at the level of knowledge only. Two of the participants think that the students' lack of sufficient knowledge is due to the complexity of the use or functioning of the energy resources. One participant thinks that students do not have enough information because focused on university examination subjects at school, one is that the media does not raise awareness on the issue.

Table 7 presents the teachers' answers to the question "What kind of changes can the awareness of students about energy resources cause in the society?". 
Table 7. Reflections of students' awareness about energy resources on the society

\begin{tabular}{lccc}
\hline \multicolumn{1}{c}{ Code } & $f$ & Teacher Code \\
\hline Provides awareness of the society & 5 & $\begin{array}{c}\text { PT1, BT2, BT3 } \\
\text { BT1, CT2 }\end{array}$ \\
\hline $\begin{array}{l}\text { Wastage and unconscious consumption can be } \\
\text { prevented }\end{array}$ & 2 & PT2, CT2 \\
$\begin{array}{l}\text { Increases awareness in terms of orientation towards } \\
\text { clean energy sources in the society }\end{array}$ & 2 & CT1, CT2 \\
\hline $\begin{array}{l}\text { Contributes to sustainability and reaching future } \\
\text { generations }\end{array}$ & 2 & CT1, CT2 \\
$\begin{array}{l}\text { Provides information about the benefit/harm status of } \\
\text { energy resources }\end{array}$ & 1 & CT1 \\
\hline
\end{tabular}

According to Table 7, five of the teachers think that the individual who becomes conscious as a result of informing and awareness-raising the students will also raise awareness of other members of society. Two of the teachers stated that waste and unconscious consumption can be prevented, two of that increase awareness in terms of orientation towards clean energy sources in the society. Two of teacher stated that the individual who becomes conscious as a result of informing and awareness-raising the students will contribute to sustainability and reaching future generations, one is that provides information about the benefit/harm status of energy resources.

Table 8 presents the teachers' answers to the question "What do you think should be included in the scope of the issues related to energy resources?"

Table 8. The scope of the course topics related to energy resources

\begin{tabular}{llc}
\hline \multicolumn{1}{c}{ Code } & $f$ & Teacher Code \\
\hline Source/power plant types in our country & 4 & PT1, PT2, BT1, CT2 \\
\hline $\begin{array}{l}\text { The importance of the energy usage and } \\
\text { need for energy }\end{array}$ & 3 & PT1, BT3, CT2 \\
\hline Benefits and harms of power plants & 3 & BT1, CT1, CT2 \\
\hline Ways of obtaining energy & 3 & PT1, PT2, BT3 \\
\hline Efficient energy use & 3 & PT1, PT2, BT1 \\
\hline $\begin{array}{l}\text { How to build facilities without harming } \\
\text { the environment }\end{array}$ & 2 & PT1, BT1 \\
\hline Energy resources financial dimension & 1 & PT1 \\
\hline
\end{tabular}

According to Table 8, four of the participants are thinking of having resources and power plant types in our country within the scope of the subject. While three of the participants mentioned that the importance of the energy usage and need for energy should be included within the scope of the subject, three of them stated that the benefits and harms of the power plants should be included. Three of the participants stated that the ways of obtaining energy are within the scope of the subject, and three of them stated that the efficient use of energy is included within the scope of the subject. Two of the participants emphasized the inclusion of how to build facilities without harming the environment within the scope of the energy resources issues, while one emphasized the energy resources financial dimension included in the agenda. 
Table 9 presents the teachers' answers to the question "What kind of teaching materials can be preferred in raising energy literate individuals?".

Table 9. Teaching materials that can be used in teaching on energy resources

\begin{tabular}{lcc}
\hline \multicolumn{1}{c}{ Code } & $f$ & Teacher Code \\
\hline Digital sources (videos, images, TV programs, ect.) & 3 & BT1, BT2, CT1 \\
\hline Energy conversion experiment sets & 2 & PT1, CT2 \\
\hline Students can produce materials themselves & 2 & PT1, BT3 \\
\hline STEM activities can be used & 1 & PT2 \\
\hline Books, newspapers, magazines, etc. & 1 & BT1 \\
\hline
\end{tabular}

According to Table 9, three of the teachers stated that digital sources could be teaching materials. Two of the teachers stated that energy conversion experiment sets can be used as teaching materials, two of them stated that students can produce their materials. One of teacher stated that STEM activities can be used, one teacher stated that books, newspapers, magazines, etc. can be used as teaching materials.

Table 10 presents the teachers' answers to the question "Can out-of-school learning environments be used as an effective learning environment in the teaching of energy-related subjects? If so, which environments can be an example?".

Table 10. Energy resources and out-of-school learning environments

\begin{tabular}{cllc}
\hline & \multicolumn{1}{c}{ Code } & $f$ & Teacher Code \\
\hline \multirow{3}{*}{$\begin{array}{c}\text { Can be } \\
\text { used }\end{array}$} & \begin{tabular}{l} 
Power plants (streams, wind, wave, etc.) \\
\cline { 2 - 4 }
\end{tabular} & 6 & $\begin{array}{c}\text { PT1, PT2, BT1, BT2, } \\
\text { BT3, CT1 }\end{array}$ \\
\cline { 2 - 4 } & Internet environments (web sites, etc.) & 1 & BT1 \\
\cline { 2 - 4 } & Science centers & 1 & BT3 \\
\hline
\end{tabular}

When the data in Table 10 are examined, it seems that all of the participants think that out-ofschool learning environments can be used as an effective learning environment in the teaching of energy-related subjects. Six of the teachers think that power plants can be used as an out-ofschool learning environment in teaching energy-related subjects. While one of the teachers mentioned that internet environments can be used for learning out of school, one thinks that science centers can be used for this purpose. A teacher thinks that recycling and waste centers can be used as an out-of-school learning environment for teaching energy resources.

\section{DISCUSSION, CONCLUSION AND RECOMMENDATIONS}

In this section, for the research, the results of the deficiencies regarding the energy resources and the opinions about the energy literacy among the students obtained from high school physics, chemistry and biology teachers are included.

The study focused on examining high school teachers' knowledge and opinions about energy literacy, the importance of energy literacy, deficiencies in students, the reflections of informing students about energy resources, the scope of lesson topics related to energy resources, and the use of learning environments outside of school in energy resources education. The results obtained in the research are presented considering the studies in the related literature. 
When the interview answers regarding the definition of energy literacy are examined; it is seen that the teachers define energy literacy as having knowledge about energy, knowing the benefits and harms of energy, knowing energy types, using energy economically, knowing about energy production methods, having awareness about energy, to relate the energy issue with daily life. In the literature, energy literacy is explained as understand about energy-related things, solving energy-related problems, realizing the environmental, social, and global effects of energy use, making informed choices of individuals in their daily lives, and having information about energy production and consumption (DeWaters \& Powers, 2011; Fah et. al., 2012; Öykün \& Abbasoğlu, 2017). Teachers' views on energy literacy are similar to the literature in terms of subjects such as having knowledge about energy and associating energy issues with daily life. In addition, teachers' views differ from the literature in terms of economical use of energy and knowing the production processes of energy.

It is thought that the explanations of teachers are related to knowing theoretical information about energy because, as we saw in Table 1, acquisitions are aimed at giving information in course curriculums. In his study, Karakaş (2019) emphasized that cognitive, affective, and behavioral gains coexist in the concept of energy literacy, and therefore it is not sufficient to give only knowledge about the concept of energy, and it is necessary to contribute to raising energy literate individuals in a context in which individuals exhibit affective reactions and turn them into behavior. Besides, some teachers have given answers regarding energy literacy, awareness of energy, and being able to relate energy to daily life. We know that the physical conditions and opportunities of a school play a significant role in the implementation of the curriculum (Pehlivan, 2004). For this reason, we think that the teachers to touch on the practical and behavioral dimension of energy literacy is that both teachers work in private schools and therefore their opportunities as laboratory implications, material, and technologic tool variety, etc. for in-class activities are more flexible. In addition, studies in the literature show that private schools support the practices and offer opportunities for teachers to carry out in-class activities (Ünsal \& Çetin, 2019).

The responses given by the teachers in Table 3 regarding the characteristics of the energy literate individual are towards the awareness that the individual should have such as being knowledgeable and conscious about the energy, caring about his country, be informed about waste of energy, paying attention to the environment and the ecosystem, participate in studies on the protection of resources, have an interest in the energy issue. Similarly, the energy literate individual is defined in the literature as knowledgeable and conscious about energy and energy consumption and paying attention to energy conservation (Valhov \& Treagust, 1988; Fah et.al., 2012; Bodzin, et. al., 2013). Unlike the literature, teachers stated that energy literate individual is who care about their country.

Teachers think that energy literacy is important for our country in terms of public awareness, increased awareness of energy-saving, development of the country, economic contribution, efficient energy use, and sustainability. This view of teachers can be interpreted as they think that an individual who is knowledgeable about energy and consciousness in the country will contribute economically and socially in terms of sustainability and savings, similar to how they define the energy literate individual. This situation is similarly explained in the literature as energy is the primary source of economic and social development, so the future depends on the 
correct use of energy resources, and it is significant to educate societies on this issue (Külekçi, 2009).

Energy sources such as oil, natural gas, and coal, which we frequently prefer, are estimated to be exhausted in a short time, and this situation is thought to cause energy crises to occur. Koç and Şenel (2013) mentioned that our country is below world averages in terms of energy density. Considering this situation, energy literacy is of great importance in many social and economic fields both for the world, our country, and society this situation supports the opinions of teachers. Also, a teacher commented that we will fail in the class on this issue regarding the importance of energy literacy for our country. It is thought that the teacher has this view because the society does not care about energy and environmental issues sufficiently and is not aware of them, and because they are not interested in the issues related to savings, they do not care about energy literacy. This view of the teacher is another phenomenon that shows that we need to change behavior towards socially efficient energy use (Oluk, Kaya-Şengören \& Babadağ, 2019).

The teachers stated that the curriculum was not sufficient, and the subject remained only at the level of knowledge as the reason for the lack of sufficient knowledge about the energy resources of the students. In his research, Töman (2011) stated that the lack of adequate coverage of energy resources in the curriculum caused incomplete learning about energy resources. Also, the teachers in our study stated that students did not have enough information due to problems such as the lack of interest in the subject expression, insufficient emphasis on the subject, the use of energy resources, or the complexity of the operation, and the lack of awareness of the visual media. In the studies in the literature, it has been stated that the occurrence of students did not have enough information caused the issue of energy with theoretical information that does not involve the problems in the current life, as well as the lack of sufficient coverage in these textbooks and curricula (Töman, 2011).

Regarding the social consequences of raising students' awareness of energy resources, teachers stated that the conscious student will also raise awareness of another and its environment, raise the awareness of the society, prevent wastage, focus the clean energy sources and contribute to sustainability. It can be interpreted that the reason for the teachers' opinions is that they will change society and the future starting from their environment as a result of their awareness (Külekçi, 2009).

Regarding the teaching materials that can be used in the teaching of energy resources, teachers suggested that can create awareness such as videos, images, TV programs that will attract their attention and be catchy for them, and experiment sets, STEM activities, and students' material production with the view that learning by living will be more memorable. Teaching in schools in traditional ways and through presentation removes the student from the subject and makes the information a memorizing phenomenon only (Göcük, 2015). Puspitarini and Hanif (2019) in their study results mentioned that make students more interested in the learning process using media other than books. This is also explaining as another alternative in the learning process is needed to improve students' learning motivation (Puspitarini \& Hanif, 2019). This situation explains that the subject about energy is not permanent and does not raise awareness since it cannot be enriched. In this context, materials that are highly memorable and noticeable should be used in the teaching of energy resources to help students raise awareness about energy. 
All of the teachers think that out of school learning environments can be effective for teaching energy-related subjects. They mostly gave power plants as an example of these learning environments. Some teachers stated that in addition to the power plants, science centers, recycling, and waste centers can be used for this purpose. Similarly, Uğraş and Zengin (2018) stated that in their study, most of the teacher candidates mentioned that the most appropriate way to efficient education on subjects such as sustainable development is out of school learning environments. As stated in the literature, it has thought that the reason for these thoughts of teachers is that out-of-school learning environments are effective in learning in subjects such as energy, environment, and sustainable development (Dori \& Tal, 2000; Çavuş, Topsakal, \& Kaplan, 2013; Bostan-Sarıŏlan \& Küçüközer, 2017). While only one of the teachers talked about organizing excursions, one teacher mentioned that internet environments and virtual environments can be used for this purpose. As a reason for this situation, it was thought that it was not used despite the suggestion of out-of-school environments due to the intensity of high school physics, chemistry, and biology curricula. In their studies, Ertaş, Şen, and Parmaksızoğlu (2011) have reached findings supporting the fact that out-of-school learning environments can be used in the teaching of energy, and they found that out-of-school scientific activities have contributed greatly to students' linking the subject to daily life.

As a result, no difference was observed in terms of teachers' branches regarding energy literacy and the insufficient knowledge of students regarding energy resources. Besides, it has been determined that some teachers are not fully informed about energy literacy. Also, when high school physics (MEB, 2018b), biology (MEB, 2018a) and chemistry (MEB, 2018c) curriculums are examined it is seen that energy literacy is not defined as a concept or acquisition (Table 1). So, it is thought that the reason for this situation is that energy literacy is not included in the curriculum of our country in terms of definition and gain. In the literature, this situation has been explained in various studies as the need to include more energy in the subject of energy and renewable energy sources, energy literacy in daily life, the effects and consequences of energy use, and the social importance of energy in education programs and related course contents (Fah et. al., 2012; Atik \& Doğan, 2019).

It is seen that teachers agree on the fact that individuals are educated as energy literate, and this is important for our country, to prevent waste and unconscious consumption, the environment we live in, the future, and society. Toth et. al. (2013) stated in their research that one of the obstacles to energy-saving comes from not knowing that waste is a big problem. Similarly, Oluk et. al. (2019) stated in their study that pre-service teachers see education as a significant variable in energy-saving.

In the context of energy production, use of energy, consumption, and saving of energy, establishing the relationship between the environment and energy can be achieved by gaining energy literacy, so it is significant to raise energy literate individuals (Karakaş, 2019). As a result of our research, the opinions of the teachers are consistent with the situation in the Karakaş' (2019) study, as energy literacy will contribute to the development of our country, the correct use and conservation of energy resources will increase, and it is significant in ensuring the sustainability of energy resources. Also, research has shown that in educational programs of various educational institutions from primary education to higher education, energy resources have not given sufficient importance (Alkan, 2009; Aktamış, 2011; Çakirlar-Altuntaş \& Turan, 2018). As stated in the sample sentences, it is substantial that not only students but also every 
individual in the country have this knowledge and consciousness, energy awareness, and they be energy literate individuals.

Determining and increasing the awareness level of young people who will be the decisionmakers in the future regarding energy resources is significant in many social and economic aspects for a livable future. For this reason, it is of great importance to renew or enhance the curriculum in this direction by raising young people as individuals with awareness based on the opinions of the teachers.

When things had considered as a whole it is seen that energy literacy and education in terms of energy resources are significant.

According to the results of the research, the recommendations made for the researchers are as follows:

- In future studies, the research can be carried out at the middle school level.

- For future studies, research can be done by increasing the sample size.

- In new researches, for helping organize energy education an energy literacy questionnaire can be developed to aims determine the energy literacy levels of high school students

- In future studies, the pre-service teachers section of the subject can be examined.

Other recommendations presented according to the research result are as follows:

- It is seen that the physics, chemistry, and biology curricula of secondary education include acquisitions at the level of knowledge about water conservation and protection of water resources, renewable and non-renewable energy resources. In addition to these, acquisitions can be include regarding the protection ways of all energy resources, application of energy resources, or project development.

- The concept of energy literacy is not defined in the curriculum. It should be defined as a sub-branch of science literacy, understanding the role of energy in our lives and finding answers to energy-related problems and behaviorally reflecting energy-related consciousness into life.

- Visual materials such as videos and activities can be preferred in teaching energy subjects.

\section{REFERENCES}

Aktamis, H. (2011). Determining energy saving behaviour and energy awareness of secondary school students according to socio-demographic characteristics. Educational Research and Reviews, 6(3), 243-250.

Alkan, M. A. (2009). Türkiye'deki yenilenebilir enerji kaynaklarının eğitimi ve öğretimi. Yayımlanmamış yüksek lisans tezi, Afyonkarahisar Kocatepe Üniversitesi, Fen Bilimleri Enstitüsü, Afyonkarahisar.

Altun, A. (2015). Medya okuryazarlığı eğitimine yönelik Türkçe yayınlar: Bir bibliyografya denemesi. Ordu Üniversitesi Sosyal Bilimler Dergisi, 9, 5-15. 
Aşıcı, M. (2009). Kişisel ve sosyal bir değer olarak okuryazarlık. Değerler Ĕ̆itimi Dergisi, 7(17), 926.

Atik, A., \& Doğan, Y. (2019). High school students' views on global climate change. Academy Journal of Educational Sciences, 3(1), 84-100.

Ayyıldız, Y., Aydın, A., \& Nakiboğlu, C. (2019). 2018 yılı ortaöğretim kimya dersi öğretim programı kazanımlarının orijinal ve yenilenmiş Bloom taksonomisine göre incelenmesi. Mehmet Akif Ersoy Üniversitesi Ĕ̆itim Fakültesi Dergisi, (52), 340-376.

Bodzin, A. M., Fu, Q., Peffer, T. E., \& Kulo, V. (2013). Developing energy literacy in US middlelevel students using the geospatial curriculum approach. International Journal of Science Education, 35(9), 1561-1589.

Bostan-Sarıoğlan, A., \& Küçüközer, H. (2017). Fen bilgisi öğretmen adaylarının okul dışı öğrenme ortamları ile ilgili görüşlerinin araştırılması. İnformal Ortamlarda Araştırmalar Dergisi, 2(1), 1-15.

Büyüköztürk, Ş., Akgün, Ö. E., Demirel, F., Karadeniz, Ş., \& Çakmak, E. K. (2016). Bilimsel araştırma yöntemleri. Ankara: Pegem Akademi.

Calp, Ş. (2020). I belong to this world! A teacher practice for developing relatedness in the school environment. European Journal of Education Studies, 7(1), 22-40.

Çakirlar Altuntaş, E., \& Turan, S. L. (2018). Awareness of secondary school students about renewable energy sources. Renewable Energy, 116, 741-748.

Çakmak, E. (2013). Kil tabletten tablet bilgisayara okuryazarlık. Sosyal bilgiler için çoklu okuryazarlıklar içinde. s.1-21. Ankara: Pegem Akademi.

Çavuş, R., Topsakal, Ü. U., \& Kaplan, A. Ö. (2013). İnformal öğrenme ortamlarının çevre bilinci kazandırmasına ilişkin öğretmen görüşleri: Kocaeli bilgievleri örneği. Pegem Eğitim ve Öğretim Dergisi, 3(1), 15-26.

DeWaters, J. E., \& Powers, S. E. (2011). Energy literacy of secondary students in New York State (USA): A measure of knowledge, affect, and behavior. Energy Policy, 39(3), 1699-1710.

Dori, Y. J., \& Tal, R. T. (2000). Formal and informal collaborative projects: Engaging in industry with environmental awareness. Science Education, 84(1), 95-113.

Ertaş, H., Şen, A. İ. \& Parmaksızoğlu, A. (2011). Okul dışı bilimsel etkinliklerin 9. sınıf öğrencilerinin enerji konusunu günlük hayatla ilişkilendirme düzeyine etkisi. Necatibey Ĕ̆itim Fakültesi Elektronik Fen ve Matematik Eğitimi Dergisi, 5(2), 178-198.

Fah, L. Y., Hoon, C. K., Munting, E. T., \& Chong, C. A. (2012). Secondary school students' energy literacy: Effect of gender and school location. OIDA International Journal of Sustainable Development, 3(7), 75-86.

Göcük, A. (2015). Probleme dayalı öğrenme yaklaşımı ile beşinci sınıf öğrencilerinde enerji okuryazarlığının geliştirilmesi. Yayımlanmamış yüksek lisans tezi, Marmara Üniversitesi, Eğitim Bilimleri Enstitüsü, İstanbul. 
Kanl, İ. B. \& Kaplan, B. (2018). A model suggestion for effıcient use of renewable energy sources urban energy cooperatives. Research Journal of Politics, Economics and Management, 6(4), $31-42$.

Karakaş, H. (2019). Sürdürülebilir kalkınma temelinde paris iklim anlaşmasına yönelik sınıf öğretmeni adaylarının görüşleri. 3. Uluslararası ÜNIDOKAP Karadeniz Sempozyumu "SürdürülebilirTarım ve Çevre", Tokat, 21-23 Haziran 2019.

Karasar, N. (2014). Bilimsel araştırma yöntemi. Ankara: Nobel Yayıncılık.

Koç, E., \& Şenel, M. C. (2013). Dünyada ve Türkiye'de enerji durumu-genel değerlendirme. Mühendis ve Makina, 54(639), 32-44.

Kuhn, D. J. (1980). The development and application of an energy opinionnaire. The Journal of Environmental Education, 11(4), 25-28.

Külekçi, Ö. C. (2009). Yenilenebilir enerji kaynakları arasında jeotermal enerjinin yeri ve Türkiye açısından önemi. Ankara Üniversitesi Çevrebilimleri Dergisi, 1(2), 83-91.

Martins, A., Madaleno, M., \& Dias, M. F. (2019, October). Energy literacy: Does education field matter? In Proceedings of the Seventh International Conference on Technological Ecosystems for Enhancing Multiculturality, 494-499. Retriewed from https://doi.org/10.1145/3362789.3362938 on 1 January, 2021.

Merritt, E. G., Bowers, N., \& Rimm-Kaufman, S. E. (2019). Making connections: Elementary students' ideas about electricity and energy resources. Renewable energy, 138, 1078-1086.

Miles, M. B. \& Huberman, A.M. (1994). Qualitative data analysis: An expanded sourcebook. 2nd Edition. USA: Sage.

Millî Eğitim Bakanlığ1 (MEB), (2018a). Ortaöğretim Biyoloji Dersi (9, 10, 11 ve 12. Sinıflar) Öğretim Programi. Ankara: MEB.

Millî Eğitim Bakanlığı (MEB), (2018b). Ortaöğretim Fizik Dersi (9, 10, 11 ve 12. Sinıflar) Öğretim Programi. Ankara: MEB.

Millî Eğitim Bakanlığı (MEB), (2018c). Ortaöğretim Kimya Dersi (9, 10, 11 ve 12. Sinıflar) Öğretim Programı. Ankara: MEB.

Oluk S., Kaya Şengören, S., \& Babadă̆, G. (2019). Öğretmen adaylarının enerji tasarrufuna yönelik tutum ve davranışlarının bazı değişkenler açısından değerlendirilmesi. Dokuz Eylül Üniversitesi Buca Eğitim Fakültesi Dergisi, (47), 1-13.

Oral, M. \& Özdemir, Ü. (2017). The position of Turkey in global energy geopolitics: Opportunities and risks. Journal of History Culture and Art Research, 6(4), 948-959.

Öykün, T., \& Abbasoğlu, S. (2017). Energy literacy survey at high schools in Northern Cyprus. International Journal of New Trends in Arts, Sports \& Science Education (IJTASE), 6(2). Retriewed from http://www.ijge.info/ojs/index.php/IJTASE/article/view/658 on January, 1, 2021.

Patton, M.Q. (2002). Qualitative research and evaluation methods. 3rd Ed. USA: Sage Publications, Inc. 
Pehlivan, K. B. (2004). Sınıf öğretmeni adaylarının öğretmenlik mesleğine yönelik tutumları ve okul tutumları arasındaki ilişki. Eğitim Araştırmaları Dergisi, 14, 211-218.

Puspitarini, Y. D., \& Hanif, M. (2019). Using learning media to increase learning motivation in elementary school. Anatolian Journal of Education, 4(2), 53-60.

Savin-Baden, M., \& Howell Major, C. (2013). Qualitative research: the essential guide to theory and practice. UK: Routledge.

Toth, N., Little, L., Read J. C., Fitton D., \& Horton M. (2013). Understanding teen attitudes towards energy consumption. Journal of Environmental Psychology, 34, 36-44.

Töman, U. (2011). Enerji ve enerji ile ilgili kavramların farkh öğrenim seviyelerinde öğrenilme durumunun araştırılması. Yayımlanmamış yüksek lisans tezi, Karadeniz Teknik Üniversitesi, Eğitim Bilimleri Enstitüsü, Trabzon.

Uğraş, M., \& Zengin, E. (2019). Sınıf öğretmeni adaylarının sürdürülebilir kalkınma için eğitim ile ilgili görüşleri. Journal of Theoretical Educational Science, 12(1), 298-315.

Ültay, E., Akyurt, H., \& Ültay, N. (2021). Descriptive content analysis in social sciences. IBAD Journal of Social Sciences, 6(10), 188-201.

Ünsal, S., \& Çetin, A. (2019). Özel okul ve devlet okulunda görev yapmış sınıf öğretmenlerinin öğretim programlarını uygulamada karşılaştıkları farklılıklar. Kastamonu Education Journal, 27(4), 1541-1551.

Valhov, S. J., \& Treagust, D. F. (1988). Students' knowledge of energy and attitudes to energy conservation. School Science and Mathematics, 88(6), 452-458.

Welsh, R., \& Rivers, R. Y. (2011). Environmental management strategies in agriculture. Agriculture and Human Values, 28(3), 297-302.

Wengraf, T. (2001). Qualitative research interviewing: Biographic narrative and semi-structured methods. USA: Sage. 